\title{
An evaluation of the effect of four herbicides on some aquatic organisms
}

\author{
A. D. V. AYANSINA ${ }^{1,2 *}$ and R. G. MUHAMMAD ${ }^{2}$ \\ ${ }^{I}$ Department of Biological Sciences, Bowen University, P.M.B. 284, Iwo, Osun State, Nigeria. \\ ${ }^{2}$ Department of Microbiology, Ibrahim Badamasi Babangiga University, P.M.B. 11, Lapai, \\ Niger State, Nigeria. \\ *Corresponding author, E-mail: ayandvt@yahoo.com ; Tel: (234) 8033745549
}

\begin{abstract}
Studies were carried out on the effect of four commonly used herbicides (2,4-D atrazine, atrazine + metolachlor and paraquat) on some aquatic organisms in simulated aquatic ecosystem at $100 \mathrm{ppm}, 150 \mathrm{ppm}$ and $200 \mathrm{ppm}$ of the herbicides active ingredients (ai). The effects of the herbicides on $\mathrm{pH}$, blue-green alga Aphanocapsa sp, aquatic weed -Lemna sp, tadpole (Bufo regularis) and bacterial species were investigated. While 2,4-D resulted in significant decreases in $\mathrm{pH}$ value; paraquat resulted in significant increases $(\mathrm{p}<0.05)$. Atrazine and atrazine + metolachlor treatments impacted the most on the lysis of Aphanocapsa sp as all the cells were lysed at 2 days after application. Paraquat treatments at all concentrations resulted in the death of all (20) tadpoles at 2 days after application. Complete tadpole death in atrazine + metolachlor was observed at 8 days after application at $150 \mathrm{ppm}$ and at 12 days after application at $100 \mathrm{ppm}$. A general decrease in bacterial counts relative to concentrations and days of treatment was observed with paraquat impacting the most on decreases in bacterial counts. Bacterial species isolated from untreated water samples (control) includedProteus sp, Enterobacter aerogenes, E. coli, Bacillus sp, Pseudomanas sp, Citrobacter sp, Staphylococcus aureus and Flavobacterium sp; while Bacillus (41.2\%) and Pseudomonas (56.3\%) species were the most frequently isolated bacteria from herbicide treated water samples after 14 days of treatment. Conclusively, herbicides from agricultural run-offs can impair the normal balance of the flora and fauna of the aquatic ecosystem.
\end{abstract}

(C) 2014 International Formulae Group. All rights reserved.

Keywords: Herbicides, aquatic ecosystem, pH, bacteria.

\section{INTRODUCTION}

Modern pesticides are almost all completely new synthetic chemicals previously unknown in nature. They are designed to be biologically active, and while a remarkable degree of selectivity has been achieved in some materials, as in the case of some sensitive herbicides and insecticides, it is not surprising that pesticides may produce undesirable effects, particularly if they are mis-used (ICI, 1978; Alexander, 1995). As a result of this the benefits derived from pesticide use may be accompanied by some disadvantages. Pesticides are designed to be biologically active and, while every effort is made to ensure that this activity is confined to the intended target, absolute specificity has not been achieved and non-target organisms may be at risk (Pimentel, 1995; Ayansina and Oso, 2006). It has been estimated that as just 
little as one percent of the applied pesticides actually reaches the target pest (Somerville, 1987; Vogel et al., 2008).

Pesticides get into aquatic ecosystems in several ways: they may be applied directly for control of aquatic plants and animals, they may reach the water body by accident when nearby land has been sprayed or they enter as spray drift from nearby applications (Bohmont, 1997; Surekha et al., 2008).

The toxicological properties of an agricultural chemical are inherent in that molecule. Therefore, knowledge about the amount that an organism is exposed to is critical in defining the risk associated with a specific use (Shurdt and Vacarro, 1996). This relationship between exposure level and the level at which toxic response is likely to occur as observed in controlled or animal toxicological studies assists with the characterization of human and animal health risk.

Dispersion of pesticides in the environment by surface run-off from agricultural fields has been a major concern in recent times. Early concerns centred primarily on the persistence of chlorinated hydrocarbon insecticides that were transported by both water and air far from their site of application (Nicholson et al., 1966). Aquatic life forms were acutely affected at low concentrations and both chronic and acute effects were associated with biological magnification in food chain (Leonard, 1989). When field runoff containing pesticide enters an aquatic ecosystem concentrations are rapidly diluted and are also partitioned among various components of the hydrosphere (Leonard, 1989). Transport and deposition of pesticides from agriculturally intensive areas to adjacent non-agricultural areas are well documented (LeNoir et al., 1999; Davison et al., 2002).

The presence of atrazine and metolachlor in surface water systems is a concern because of their potential adverse effect on human and animal health, and aquatic ecosystems. Health problems associated with these pesticides includes cancer, nervous system disorders, birth detects and male sterility (Gupta, 2004). The herbicide 2,4-D widely used for cereals cultivation has been found in aquatic ecosystems, being accumulated in large cells at concentrations exceeding by many times its content in the environment (Gogotov, 1992). Moreover, pesticides have been found in the bodies of frogs from areas where pesticide use has not occurred historically (Russell et al., 1997). Agricultural run-off of pesticides can also have adverse effects on amphibians because pesticides have been detected at amphibian breeding sites almost a year after application (Hayes et al., 2003).

In the present study, we investigated the effect of four commonly used herbicides in South-western Nigeria: 2,4-D, atrazine, atrazine + metolachlor and paraquat on a simulated aquatic ecosystem at $100 \mathrm{ppm}, 150$ ppm and 200 ppm (ai). Effect of these herbicides on $\mathrm{pH}$, blue-green algaAphanocapsa sp, aquatic weed Lemna sp, tadpole (Bufo regularis) and bacterial counts and species was carried out with a view to assessing the toxicological effect of these herbicides on test organisms.

\section{MATERIALS AND METHODS}

Water samples and herbicide
concentrations
Five water samples (50 litres each)
were collected from the Awba dam (a river running through the University of Ibadan) in plastic bowls and kept in the screen house. The herbicides atrazine (At), atrazine + metolachlor (AtM), 2, 4-D and paraquat (Pq) were used for the investigation at 100, 150 and $200 \mathrm{ppm}$ of active ingredients (ai). An untreated sample was kept as control. Effect of the herbicide treatments on $\mathrm{pH}$ was carried out using the Jenway $\mathrm{pH}$ meter (model 3150 ).

\section{Effect of herbicide concentration on blue- green algae}

A 24-hour old liquid culture of actively growing culture of Aphanocapsa sp. was used for the investigation. Thirty milliliters each from the herbicide treated water samples were measured into sterile $150 \mathrm{ml}$ conical flasks. 
Five mililitres of the replicate liquid culture were then introduced into each of the conical flasks. An actively growing culture of Aphanocapsa sp was kept as control.

Viable cells (means) appearing greenish when viewed on the Neubauer haemocytometer were counted (positive) daily for 7 days while dead cells appeared as brownish debris.

Effect of herbicide concentration on aquatic weed (Lemna sp.)

Effect of different concentrations of herbicides on aquatic plant was carried out using Lemna sp. obtained from the Awba dam, University of Ibadan. Two litres of the different concentrations of the herbicide treated water samples were measured into plastic bowls. Fifty seedlings each of the Lemna sp. were thereafter introduced into the herbicide-water mixture. Number of wilted (from green to whitish-yellow) seedlings was noted and recorded over a period of 7 days.

Effect of herbicide concentration on tadpoles (Bufo regularis)

Effect of different concentrations of herbicide on actively growing tadpoles was carried out. Tadpoles were collected from the same stream where the water sample was collected. Twenty tadpoles each were introduced into the treated water samples in the bowls and observed for 14 days. Number of dead (sinking and immobile) tadpoles were carefully noted and counted.

\section{Total viable bacteria counts}

Ten-fold dilutions of each of the treated water samples were carried out. This was done by pipeting $1.0 \mathrm{ml}$ of each sample water into $9.0 \mathrm{ml}$ of sterile distilled water to give $10^{-}$ ${ }^{1}$ dilution. Further dilutions were carried out to the seventh dilution and plated out on plate count agar for enumeration of viable bacterial counts. Bacterial identification was carried out using different biochemical and physiological tests- some of which includes Gram's staining, endosperm staining, catalase test, oxidase test, motility test, citrate utilization test and sugar fermentation test.

\section{Statistical analysis}

Data generated were subjected to analysis (ANOVA) using the SPSS package.

\section{RESULTS}

The effect of herbicide application on the $\mathrm{pH}$ of the stream water sample is presented on Table 1. Application of 2,4-D resulted in decrease in $\mathrm{pH}$ at all concentrations. However, paraquat application resulted in significant increases in the $\mathrm{pH}$ values at all levels of concentrations $(\mathrm{P}<0.05)$. Atrazine treatments at 100 and $200 \mathrm{ppm}$ and atrazine + metolachlor at 100 and $150 \mathrm{ppm}$ resulted in significant changes in the $\mathrm{pH}$ $(\mathrm{P}<0.05)$.

Table 2 shows the effect of herbicide concentrations on the blue-green alga Aphanocapsa sp. An initial small increase in cell count was observed in the control sample reaching a maximum by the third day ( 25 cells). Atrazine and atrazine + metolachlor treatments resulted in more lethal effect than the other two herbicides. Within the first 24 hours of application there was significant cell lysis with just between one or two cells able to survive the two herbicides. In paraquat treated water samples an average of ten cells each were observed in 100 and $150 \mathrm{ppm}$ concentrations. The effect of herbicide treatments on the aquatic weed as expressed by the number of wilted seed-leaves as shown in Table 3. Paraquat and Atrazine + metolachlor impacted the most in the wilting of this aquatic plant. In the two treatments, between 20 and 30 seed leaves had wilted by day one after treatment and this trend increased with time and concentration. In atrazine treated water samples, at day one between 5 and 10 seed leaves had wilted, followed by slight increases in numbers of wilted leaves with time and increases in concentrations, while in 2, 4-D treated water samples a relatively mild wilting effect was observed. By day seven, only 5 seed leaves had wilted at $100 \mathrm{ppm}$ while 10 each had wilted in $150 \mathrm{ppm}$ and $200 \mathrm{ppm}$. 
The effect of herbicide treatments on the survival of tadpoles as expressed in the number of dead tadpoles is shown in table 4. At all concentrations of paraquat, all the tadpoles had died by day 2 . In atrazine + metolachlor treated water samples all (except at $100 \mathrm{ppm}$ ) tadpoles had also died. In atrazine treated water samples, 16 tadpoles had died at $100 \mathrm{ppm}, 18$ in $150 \mathrm{ppm}$ and 20 in $200 \mathrm{ppm}$ by day 2. Complete tadpole death was observed at day 8 at $150 \mathrm{ppm}$, while complete death was observed at day 12 in 100 ppm. However, 2,4-D treatment resulted in mild lytic effect on growth tadpoles. By day two, 6 tadpoles each had died at all the concentrations. While maximum death of 8 tadpoles was observed at $150 \mathrm{ppm}$ and 200 ppm from day 10 onward.

Figures 1, 2 and 3 show the effect of herbicide concentrations on mean viable bacterial counts in treated stream water samples. Different concentrations of the herbicides resulted in significant reductions in bacterial counts in treated water samples compared to the control $(\mathrm{P}<0.05)$. Compared to other herbicides, paraquat resulted in the most significant reduction in bacterial counts; this was followed by atrazine + metolachlor treatment.

Major bacteria isolated from untreated (control) water samples and herbicide treated water samples are presented in table 5 . Bacteria isolated from the control water samples are those common in surface water bodies. Herbicide treatments resulted in elimination of Enterobacter aerogenes, Proteus sp, E. coli, Ciltrobacter sp, Staphylococcus aureus, and Flavobacterium sp. Bacillus (41.2\%) and Pseudomonas $(56.3 \%)$ species were the most frequently isolated bacteria from herbicide treated water samples.

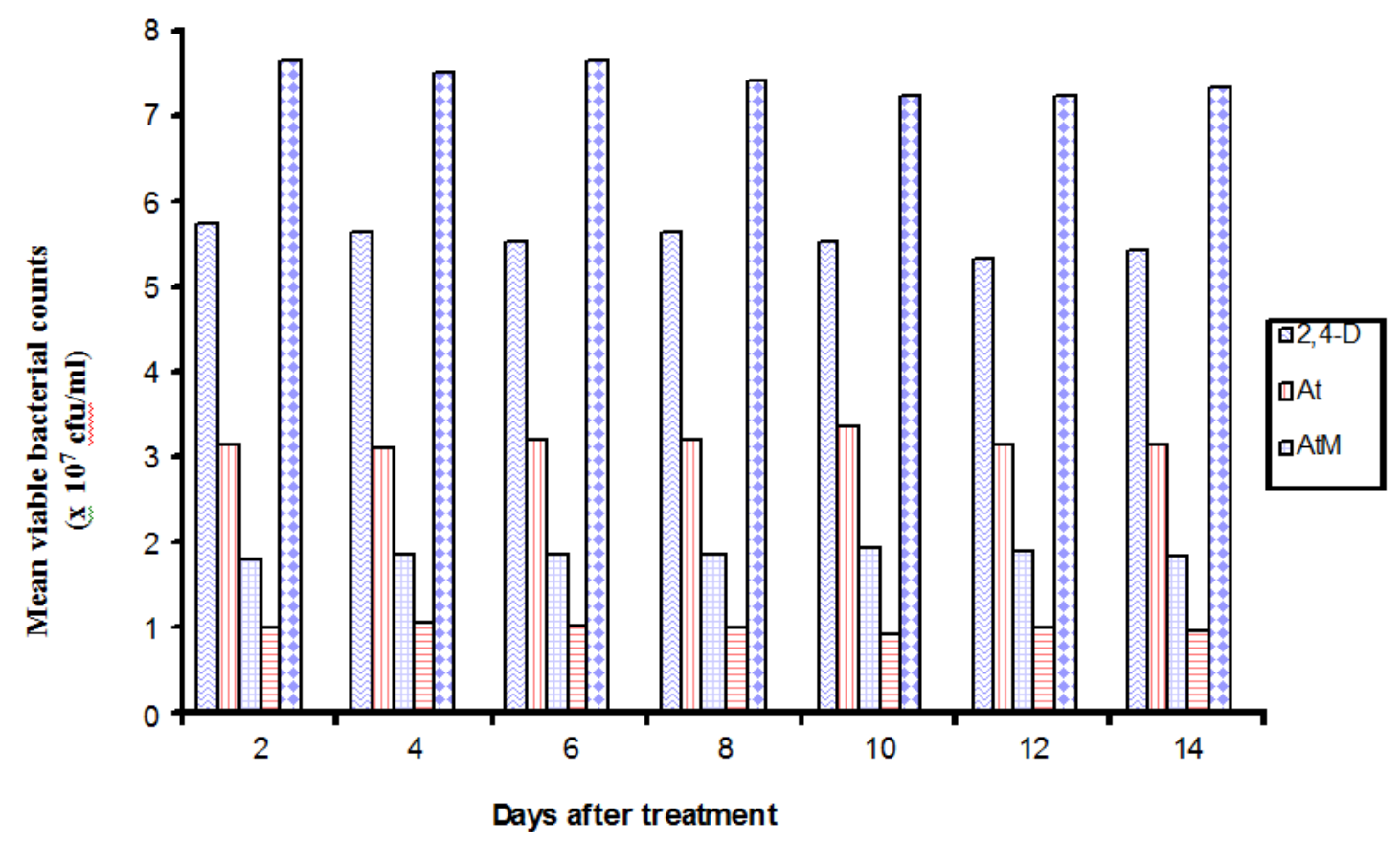

Figure 1: Effect of herbicides on mean viable bacterial counts at $100 \mathrm{ppm}$. 


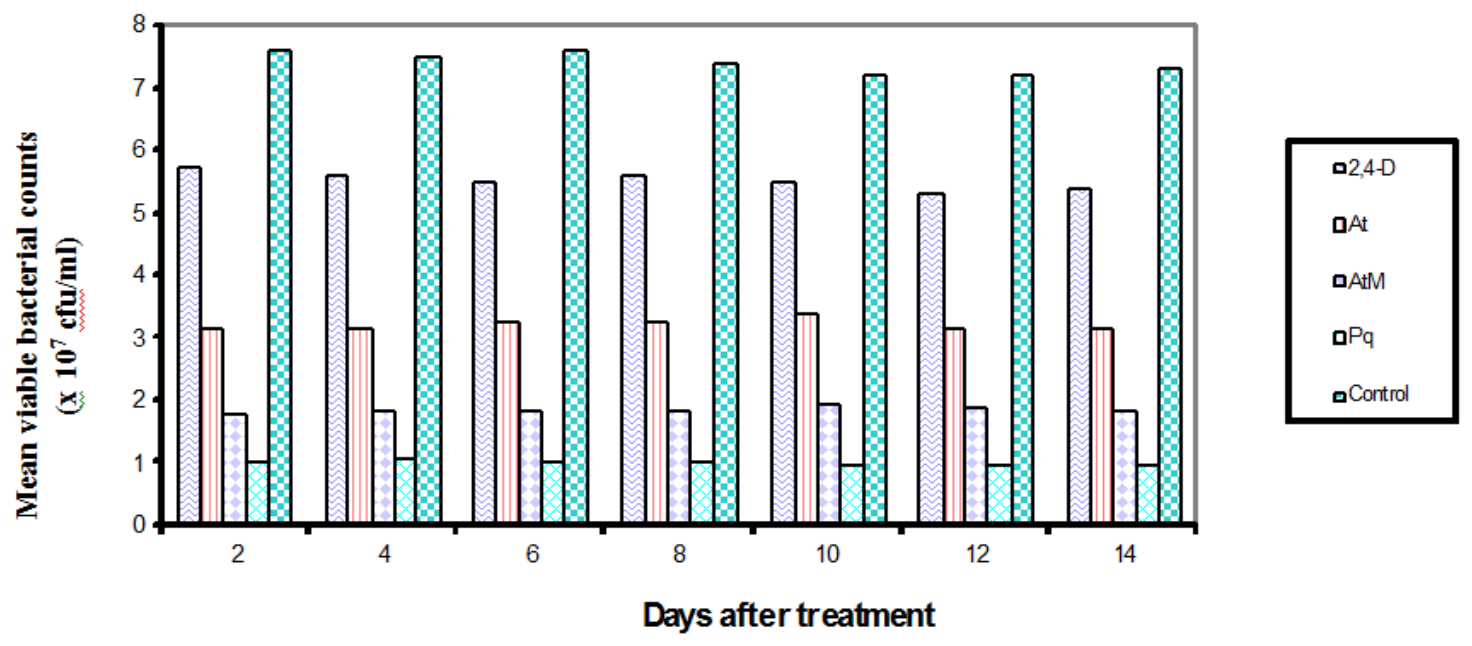

Figure 2: Effect of herbicides on mean viable bacterial counts at $150 \mathrm{ppm}$.

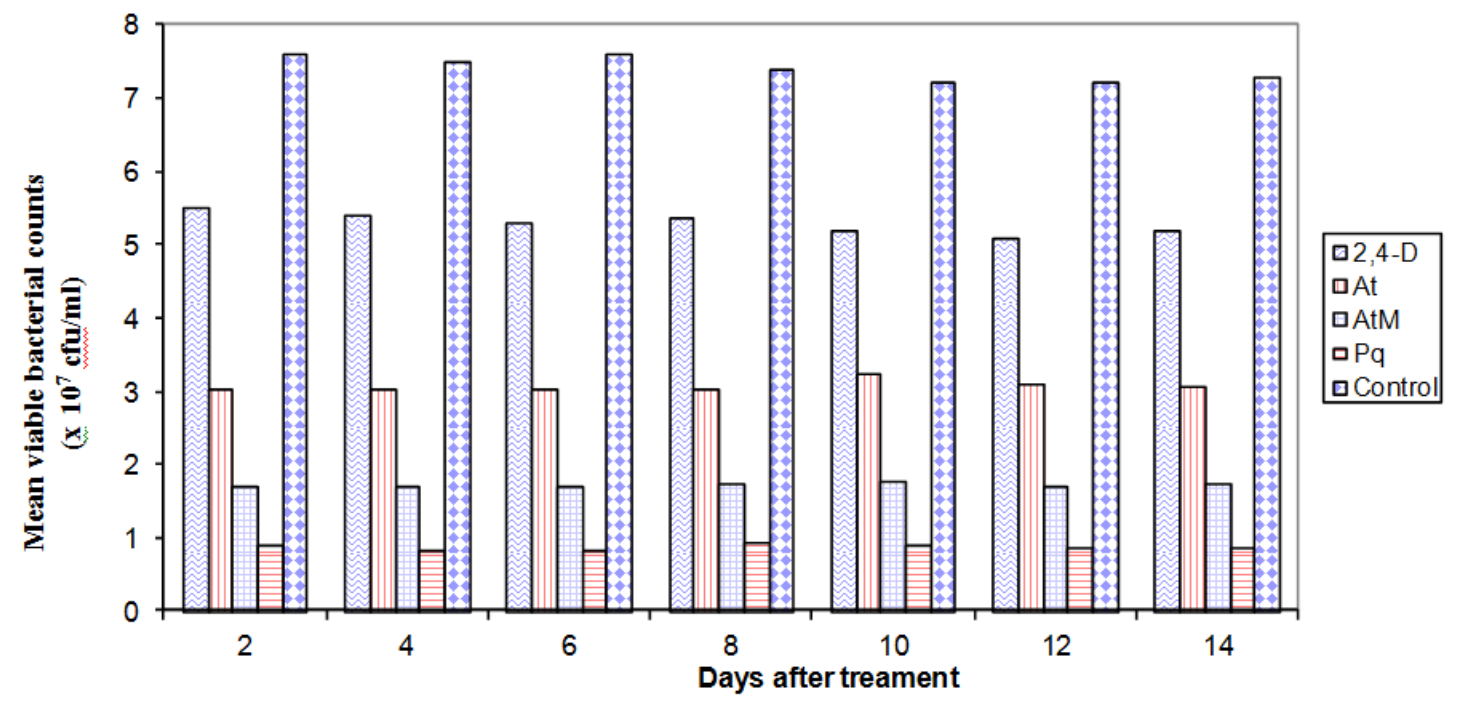

Figure 3: Effect of herbicides on mean viable bacterial counts at $200 \mathrm{ppm}$. 
A. D. V. AYANSINA and R. G. MUHAMMAD / Int. J. Biol. Chem. Sci. 8(1): 304-313, 2014

Table 1: $\mathrm{pH}$ measurements in herbicide treated stream water samples $(\mathrm{p}=0.05)$.

\begin{tabular}{|c|c|c|c|c|c|c|c|c|c|c|c|c|}
\hline Herbicide conc. (ppm) & Day 0 & Day 2 & Day 4 & Day 6 & Day 8 & Day 10 & Day 12 & Day 14 & $\mathbf{X}$ & Variance & t- cal & Statistical Significance \\
\hline Control & 8.30 & 8.34 & 8.32 & 8.36 & 8.40 & 8.42 & 8.35 & 8.33 & 8.35 & 0.002 & - & - \\
\hline \multicolumn{13}{|l|}{$2,4-\mathrm{D}$} \\
\hline 100 & 7.60 & 7.65 & 7.64 & 7.63 & 7.53 & 7.79 & 7.61 & 7.49 & 7.62 & 0.008 & -21.23 & Significant \\
\hline 150 & 7.81 & 7.85 & 7.88 & 7.85 & 7.75 & 7.97 & 7.81 & 7.79 & 7.82 & 0.002 & -26.16 & Significant \\
\hline 200 & 7.74 & 7.65 & 7.71 & 7.63 & 7.67 & 7.63 & 7.62 & 7.79 & 7.68 & 0.004 & -25.97 & Significant \\
\hline \multicolumn{13}{|l|}{ At } \\
\hline 100 & 8.20 & 8.25 & 8.21 & 8.31 & 8.32 & 8.36 & 8.28 & 8.15 & 8.26 & 0.005 & -3.22 & Significant \\
\hline 150 & 8.31 & 8.34 & 8.39 & 8.22 & 8.33 & 8.24 & 8.43 & 8.53 & 8.35 & 0.001 & -0.0097 & Not Sign. \\
\hline 200 & 8.15 & 8.26 & 8.21 & 8.28 & 8.25 & 8.30 & 8.23 & 8.11 & 8.22 & 0.004 & -4.79 & Significant \\
\hline \multicolumn{13}{|l|}{ AtM } \\
\hline 100 & 8.30 & 8.37 & 8.35 & 8.41 & 8.38 & 8.22 & 8.40 & 8.47 & 8.36 & 0.006 & 0.33 & Significant \\
\hline 150 & 8.41 & 8.35 & 8.38 & 8.25 & 8.32 & 8.20 & 8.41 & 8.55 & 8.36 & 0.001 & 0.154 & Significant \\
\hline 200 & 8.23 & 8.31 & 8.28 & 8.33 & 8.21 & 8.17 & 8.40 & 8.49 & 8.30 & 0.011 & -1.26 & Not Sign. \\
\hline \multicolumn{13}{|l|}{$\mathrm{Pq}$} \\
\hline 100 & 8.20 & 8.25 & 8.23 & 8.35 & 8.37 & 8.30 & 8.29 & 8.15 & 8.27 & 0.006 & -2.84 & Significant \\
\hline 150 & 8.35 & 8.41 & 8.39 & 8.37 & 8.41 & 8.34 & 8.38 & 8.43 & 8.39 & 0.001 & 1.81 & Significant \\
\hline 200 & 8.31 & 8.24 & 8.32 & 8.30 & 8.36 & 8.24 & 8.12 & 8.12 & 8.25 & 0.008 & -2.9 & Not Sign. \\
\hline
\end{tabular}


Table 2: Effect of herbicide concentrations on alga (Aphanocapsa Sp.) in water treated sample-cell counts as indicated by surviving cells.

\begin{tabular}{|c|c|c|c|c|c|c|c|}
\hline \multirow{2}{*}{ Treatment ppm } & \multicolumn{7}{|c|}{ Days } \\
\hline & 1 & 2 & 3 & 4 & 5 & 6 & 7 \\
\hline \multicolumn{8}{|l|}{$2,4-\mathrm{D}$} \\
\hline 100 & 12 & 6 & 5 & 4 & 4 & 4 & 2 \\
\hline 150 & 10 & 5 & 5 & 4 & 4 & 3 & 2 \\
\hline 200 & 8 & 4 & 3 & 3 & 3 & 3 & 2 \\
\hline \multicolumn{8}{|l|}{$\overline{\text { At }}$} \\
\hline 100 & 2 & 1 & 1 & 1 & 0 & 0 & 0 \\
\hline 150 & 2 & 1 & 1 & 0 & 0 & 0 & 0 \\
\hline 200 & 2 & 1 & 0 & 0 & 0 & 0 & 0 \\
\hline \multicolumn{8}{|l|}{ AtM } \\
\hline 100 & 2 & 1 & 1 & 0 & 0 & 0 & 0 \\
\hline 150 & 1 & 1 & 0 & 0 & 0 & 0 & 0 \\
\hline 200 & 1 & 0 & 0 & 0 & 0 & 0 & 0 \\
\hline \multicolumn{8}{|l|}{$\mathrm{Pq}$} \\
\hline 100 & 10 & 6 & 6 & 4 & 4 & 2 & 1 \\
\hline 150 & 10 & 4 & 4 & 3 & 2 & 1 & 0 \\
\hline 200 & 8 & 3 & 3 & 3 & 2 & 0 & 0 \\
\hline Control & 20 & 23 & 25 & 20 & 20 & 18 & 18 \\
\hline
\end{tabular}

Table 3: Effect of herbicide treatment on Lemna sp. as shown by number of wilted seed leaves.

\begin{tabular}{|c|c|c|c|c|c|c|c|}
\hline \multirow{2}{*}{ Treatment ppm } & \multicolumn{7}{|c|}{ Days } \\
\hline & 1 & 2 & 3 & 4 & 5 & 6 & 7 \\
\hline \multicolumn{8}{|l|}{$2,4-\mathrm{D}$} \\
\hline 100 & 3 & 5 & 5 & 5 & 5 & 5 & 5 \\
\hline 150 & 3 & 5 & 5 & 8 & 10 & 10 & 10 \\
\hline 200 & 5 & 5 & 10 & 8 & 10 & 10 & 10 \\
\hline \multicolumn{8}{|l|}{ At } \\
\hline 100 & 5 & 10 & 10 & 10 & 20 & 20 & 25 \\
\hline 150 & 8 & 10 & 10 & 10 & 25 & 30 & 30 \\
\hline 200 & 10 & 15 & 15 & 20 & 35 & 35 & 40 \\
\hline \multicolumn{8}{|l|}{ AtM } \\
\hline 100 & 20 & 8 & 30 & 35 & 40 & 45 & 47 \\
\hline 150 & 30 & 35 & 40 & 40 & 45 & 45 & 48 \\
\hline 200 & 30 & 35 & 40 & 45 & 48 & 48 & 48 \\
\hline \multicolumn{8}{|l|}{$\mathrm{Pq}$} \\
\hline 100 & 20 & 25 & 33 & 45 & 45 & 48 & 48 \\
\hline 150 & 25 & 25 & 38 & 45 & 45 & 48 & 48 \\
\hline 200 & 30 & 35 & 45 & 48 & 48 & 48 & 48 \\
\hline Control & 0 & 0 & 0 & 0 & 0 & 2 & 5 \\
\hline
\end{tabular}


Table 4: Effect of herbicide treatment on the survival of tadpole as shown by number of dead tadpoles (Bufo regularis).

\begin{tabular}{|c|c|c|c|c|c|c|c|}
\hline \multirow[t]{2}{*}{ Treatment ppm } & \multicolumn{7}{|c|}{ Days } \\
\hline & 2 & 4 & 6 & 8 & $\mathbf{1 0}$ & 12 & 14 \\
\hline \multicolumn{8}{|l|}{$2,4-\mathrm{D}$} \\
\hline 100 & 6 & 6 & 6 & 6 & 6 & 6 & 6 \\
\hline 150 & 6 & 6 & 6 & 6 & 6 & 8 & 8 \\
\hline 200 & 6 & 6 & 8 & 8 & 8 & 8 & 8 \\
\hline \multicolumn{8}{|l|}{ At } \\
\hline 100 & 16 & 16 & 16 & 16 & 18 & 20 & - \\
\hline 150 & 18 & 18 & 18 & 20 & - & - & - \\
\hline 200 & 20 & - & - & - & - & - & - \\
\hline \multicolumn{8}{|l|}{ AtM } \\
\hline 100 & 19 & 19 & 19 & 19 & 19 & 19 & 19 \\
\hline 150 & 20 & - & - & - & - & - & - \\
\hline 200 & 20 & - & - & - & - & - & - \\
\hline \multicolumn{8}{|l|}{$\mathrm{Pq}$} \\
\hline 100 & 20 & - & - & - & - & - & - \\
\hline 150 & 20 & - & - & - & - & - & - \\
\hline 200 & 20 & - & - & - & - & - & - \\
\hline Control & 0 & 0 & 0 & 0 & 0 & 0 & 1 \\
\hline
\end{tabular}

Table 5: Major bacterial isolates from control and herbicide treated water samples after 14 days.

\begin{tabular}{ll}
\hline Control & Herbicide treated water samples \\
\hline Enterobecter aerogenes & Bacillus spp. $(41.2 \%)$ \\
Proteus $\mathrm{spp}$ & Pseudomonas $\mathrm{spp} .(56.3 \%)$ \\
Bacillus $\mathrm{spp}$ & Unidentified $(3.5 \%)$ \\
Pseudomonas $\mathrm{spp}$ & \\
E. coli & \\
Citrobacter $\mathrm{spp}$ & \\
Staphylococcus aureus & \\
Flavobacterium spp. & \\
\hline
\end{tabular}

\section{DISCUSSION}

Major factors that can affect the action and fate of herbicides in an environment include $\mathrm{pH}$, moisture, temperature and organic matter (Ayansina and Oso, 2006). The effects of herbicide treatments in the water samples from this work shows that while 2,4-D resulted in significant decreases in $\mathrm{pH}$ other herbicides resulted in significant increases in $\mathrm{pH}$ values over time. Changes in $\mathrm{pH}$ values have the ability to determine the survival of living organisms in any environment.
It is important to understand the effects of agro-chemicals e.g. herbicides on aquatic plants, since these plants are a necessary factor for an ecosystem to exist in a healthy state (Dantin et al., 2010). Wilting (and subsequent deaths) of aquatic plants treated with herbicides in this work can be attributed to the ability of the herbicides to impair photosynthetic pigments in the plants (Manson, 1996). According to Dantin et al. (2010) the electron transport rate values were significantly reduced in the laboratory 
mesocosms that had exposure to atrazine and metolachlor at $110 \mathrm{ug} / \mathrm{L}$ each for 96 hours which is the environmentally relevant concentrations found in many large watersheds. Death of plants may also lead to increase nutrient levels and further increase in the growth rate of algae until sheer space becomes a limiting factor.

Amphibians encompass a wide variety of animal species including Bufo regularis which have been shown in this work to be adversely affected by the four herbicides used. Tavera-Mendoza et al. (2001) had shown that as small as $18 \mathrm{ug} / \mathrm{L}$ of atrazine had the capacity to reduce reproductive and growth capacities of the African tadpole (Xenopus laevis). The authors further showed that atrazine may affect the aromatase activity though they were unable to provide a mechanism by which this may occur. Death of tadpoles in herbicide treated water as observed in this work is in line with the report of Hayes et al. (2003) who had reported a direct relationship between atrazine exposure and reproductive development. Death of tadpoles in herbicide treated water observed is also similar to the work of Allran and Karasov (2001) who observed that as much as $20 \mathrm{ug} / \mathrm{L}$ of atrazine prevented metamorphosis in the American toad (Bufo americanus).

Increasing herbicide concentrations has the ability to result in reduction in both the number and species of microorganisms as also observed in this work Ayansina and Oso (2006). Bacillus sp (41.2\%) and Pseudomonas sp $(56.3 \%)$ were the predominant bacterial species isolated after fourteen days treatment. Ayansina and Oso (2008) had reported the prevalence of these two bacteria in soils treated with similar herbicides.

\section{Conclusion}

This work has shown that herbicides (and other pesticides) have the ability to adversely affect the biotic life of an aquatic ecosystem. Herbicides should therefore be carefully used since they have the ability to get into aquatic ecosystems from agricultural run-offs.

\section{ACKNOWLEDGEMENTS}

We are grateful to Prof. E. O. Fagade and Mr. Emmanuel Oleh of Department of Botany and Microbiology, University of Ibadan for supply of culture of Aphanocapsa sp used for this research.

\section{REFERENCES}

Alexander M. 1995. How toxic are toxic chemicals in soil. Environ. Sci. Technol., 29: 2712-2713.

Allran JW, Karasov WH. 2001. Effects of atrazine on embryos, larvae and adults of anuran amphibians. Environs. Toxicol. Chem., 20: 769-775.

Ayansina ADV, Oso BA. 2006. Effects of two commonly used herbicides on soil microflora at two different concentrations. African J. Biotech., 5(2): 129-132.

Ayansina ADV, Oso BA. 2008. Effect of organic amendments on microbial biomass of a tropical soil treated with some herbicides. Int. J. Biol. Chem. Sci., 2(4): 417-424.

Bohmont BL. 1997. The Standard Pesticide User's Guide. Prentice Hall Upper Seddle River NJ 07458.531.

Dantin DD, Boustany RG, Lewis, MA, Jordan SJ, Moss RF, Michot TC. 2010. Effects of nutrient pre-exposure on atrazine toxicity to Vallisneria americanus. Arch. Environ. Contam. Toxicol., 50: 622-630.

Davidson C, Shaffer HB, Jennings MR. 2002. Spatial tests of the pesticide drift, habitat destruction, UV-B, and climate-change hypothesis for California amphibians decline. Conserv. Biol., 16: 1588-1601.

Gogotov IN. 1992. Degradation of xenobiotics by phototropic microorganisms. In Fate of Pesticides and Chemicals in the Environment, Schnoor JL (ed). John Wiley \& sons: NY; 234-258.

Gupta PK. 2004. Pesticide exposure-The Indian Scene. Toxicol., 198: 83-90.

Hayes T, Haston, Tsui M, Hoang A, Haefelle C, Vonk A. 2003. Atrazine-induced hermaphrodism at $0.1 \mathrm{ppm}$ in American Leopard frogs (Rena pipiens): laboratory 
and field evidence. Environ. Health Perspect., 111: 568-575.

ICI. 1978. Pesticide and the Environment. Imperial Chemical Society, Plant Protection division, Hill Research Station: Washington, D.C.; 1-16.

LeNoir JS, McConnell LL, Fellers MG, Cahill TM, Sieber JN. 1999. Summer-time transport of current use pesticides from California's Central Valley to the Sierra Nevada mountain range, USA. Environ. Toxicol. Chem., 16: 2715-2722.

Leonard RA. 1989. Herbicides in surface Waters. In Environmental Chemistry of Herbicides (vol. 1), Grover R (ed); 45-83.

Mason CF. 1996. Water Pollution Biology: Causes, Effects and Control. Harrison RM (ed). The Royal Society of Chemistry: London; 66-92.

Newman JF. 1978. Introduction to Pesticides: Mode of Action - In Pesticide Microbiology, Hill IR, Wright SJL (eds). Academy Press; 844-887.

Nicholson H, Greenda AR, Teasley JI. 1966. Water Pollution by Insecticides. A Six year study of watershed, Water Resource Center, University of California, Davis. Proc. Symp. Agric. Waste Water, 10: 132138.

Pimentel D. 1985. Effects of pesticides on the environment. In Proc. of the $10^{\text {th }}$ Internat. Congress of Plant Protection, held in Brighton, Vol. 2, British Crop Prot. Council (BCPC), London.
Russell RW, Gillan KA, Haffner GD. 1997. Polychlorinated biphenyls and chlorinated pesticides in Southern Ontario, Canada green frogs. Environ. Toxicol. Chem., 16: 2258-2263.

Shurdut, BA, Vacarro J. 1996. Risk of Human Exposures to pesticides in the urban environment - In Proced. $48^{\text {th }}$ Annual Conf. of California Weed Science Society, Jan., 23-24, 1996. P.9-10.

Somerville L. 1987. Monitoring degradation products. In Pesticide Effects on Soil Microflora-Somerville L, Greaves MP. (ed). Taylor \& Francis Publ.: London, NY; 5-13.

Tavera-Mendoza LS, Ruby S, Brousseau P, Fournier DC, Marcogliese. 2002. Response of the amphibian tadpole (Xenopus larvis) to atrazine during sexual differentiation of the ovary. Environ. Toxicol. Chem., 21: 1264-1267.

Tierney DP, Williams M, Hann AL, Holden PW, Newby L. 1993b. Surface water monitoring for atrazine in the Chesapeake Bay Water Shade - 1976 to 1991 . In $4^{\text {th }}$ National Conference on Pesticides, Nov. 1-3, 1993, Virginia. Water Resources Centre, Virginia. P. 663-683.

Vogel JR, Majewski MS, Capel PD. 2008. Pesticides in rain in four agricultural watersheds in the United States. $J$. Environ. Qual., 37(3): 1101-1115. 